Mann, S. O., Masson, F. M. \& Oxford, A. E. (1954). J. gen. Microbiol. 10, 142-149.

\title{
Facultative Anaerobic Bacteria from the Sheep's Rumen
}

\author{
By S. O. MANN, FRANCES M. MASSON AND A. E. OXFORD \\ Rowett Research Institute, Bucksburn, Aberdeenshire
}

SUMMARY: A study has been made of some 300 facultative anaerobic strains, isolated by Heald, Krogh, Mann, Appleby, Masson \& Oxford (1953) from the rumen of a hay-fed sheep. The 120 streptococcal isolates all belonged to Lancefield's serological group D. $82 \%$ had fermentation and other reactions similar to Streptococcus bovis; $6 \%$ resembled Str. faecalis and the remainder (12\%) were unclassifiable by existing schemes. Str. faecalis could also be isolated from old hay fed to the sheep. Staphylococcal isolates were all coagulase-negative, and eleven out of twelve conformed to subgroup 2 in the classification of Shaw, Stitt \& Cowan (1951). The coliform isolates were mostly of the true intestinal type. A few strains resembled Aerobacter cloacae, but $A$. aerogenes was not encountered. The large Gram-negative sarcina-like organism, previously detected in rumen contents by Baker, Nasr, Morrice \& Bruce (1950) and by Moir \& Masson (1952), has been isolated in pure culture and named Sarcina bakeri. It ferments only glucose.

In a recent paper (Heald et al. 1953) a method of counting viable saccharolytic bacteria from a sheep's rumen was described (hereinafter referred to as the 'bottle count') in which the basal medium consisted of rumen liquor itself, suitably clarified and sterilized after withdrawal from hay-fed sheep and supplemented by nothing more than a vitamin-free mixture of amino acids, a soluble fermentable carbohydrate and agar. In this way it was hoped that only bacteria genuinely active under rumen conditions would be counted. Several categories of soluble fermentable carbohydrates were tried, including hexoses, pentoses, glucosides, oligosaccharides, sugar alcohols and three polysaccharides (amylose, inulin and bacterial levan). By picking off colonies from the agar-shake cultures, some 300 isolates were eventually obtained in pure culture representing, for the most part, small cocci and Gram-negative rods present in numbers exceeding $100,000 / g$. wet rumen contents (see Table 2 in Heald et al. 1953). Since the methods used ensured that only the active carbohydrate fermenters would grow, these isolated bacteria were regarded as of actual or potential importance in rumen fermentations. This paper is concerned with the identification of these cultures, particular attention being paid to streptococci and other Gram-positive cocci, Gram-negative cocci and small Gram-negative rods. Gram-positive rods are not abundant in the rumen of mature hay-fed sheep, and the few isolates of Heald et al. which came into this category were ignored in this present survey.

It should be emphasized that the method of counting could be relied upon to demonstrate only the facultatively anaerobic microflora, and those microaerophiles (not in evidence in this study) which had no special carbon dioxide requirement. Evidence will be presented in another paper that true microaerophiles, from the calf's rumen, can be detected by our bottle-counting technique. A comparison between these rumen bacterial isolates and the microflora of the hay fed to the sheep has also been attempted. 


\section{METHODS}

The cultures obtained by Heald et al. (all from sheep no. 879) were kept in cooked meat medium or in nutrient agar stabs, and before testing by standard bacteriological methods appropriate for the provisionally assigned genus were plated for purity on blood agar, the plates being incubated both aerobically and anaerobically. In the main the methods used for systematic study were taken from Mackie \& McCartney (1950) and the Manual of Methods for Pure Culture of Bacteria (1948-9).

With streptococcal isolates, bacillary extracts prepared by the method of Fuller (1938) were in almost every instance tested for the precipitin reaction against Lancefield's Group D antiserum (Wellcome Brand, Burroughs Wellcome and Co.).

Other Gram-positive cocci were examined by the methods of Shaw et al. (1951).

\section{RESULTS}

Identification of streptococcal isolates. All truly streptococcal isolates from the rumen belonged to Lancefield's Group D, but fell into several categories with respect to fermentation reactions. The greater number seemed to be identical with the typical starch-fermenting streptococcus of the sheep's rumen, which has been described fully by MacPherson (1953). It is usually capsulated, gives rise to slight $\alpha$-haemolysis on blood agar, ferments starch and (often) inulin, does not ferment mannitol, will grow at $45^{\circ}$ but not at pH 9.6, nor in presence of $\mathbf{6 . 5} \% \mathrm{NaCl}$. In most respects it resembles $\mathrm{Str}$. bovis (Bergey's Manual, 1948, p. 321) but apparently does not belong to the same serological type as this organism (MacPherson, 1953). It is quite distinct from Str. faecalis (Bergey, 1948, p. 325). The streptococcal isolates from our bottle counts all conformed to this (bovis) pattern when the following carbohydrates were used in the count; glucose (6 cultures isolated), sucrose (8), lactose (6), raffinose (7), salicin (19), inulin (1), amylose (6).

When mannitol, maltose or xylose was used in the bottle counts the streptococcal isolates were not all of this pattern (hereafter denoted $\mathbf{0 0}++$, the signs signifying no growth at $\mathrm{pH} \mathbf{9 \cdot 6}$, no fermentation of mannitol, but fermentation of starch and inulin respectively). Many of the mannitol bottle isolates were surprisingly of this pattern or of pattern $+0++$, i.e. they did not ferment mannitol after isolation, but representatives of patterns $\mathbf{0}+++, \mathbf{0}++\mathbf{0}$, ++00 and +++0 (all fermenting mannitol) were also found. Of strains from the maltose bottles nearly $50 \%$ were of the pattern $+0++$, whilst both of the xylose bottle strains were of the pattern ++00 , i.e. typical $S t r$. faecalis. Those strains from mannitol and maltose which grew at pH $9 \cdot 6$ (see Shattock \& Hirsch, 1947, for the usual significance of this behaviour) and yet were not the typical Str. faecalis by fermentation reactions were further tested for growth in $6.5 \% \mathrm{NaCl}$. Only one strain out of fourteen grew, and this was regarded as a starch-fermenting strain of Str. faecalis, so bringing the total number of Str. faecalis isolates to seven out of sixty-seven. The strains with pattern $0+++$ were regarded as atypical representatives of the amylolytic 
rumen streptococcus with the added power of fermenting mannitol, so bringing the total number of these organisms to forty-five. Thus only fifteen streptococcal isolates (of patterns $0++\mathbf{0}$ and $+0++$ ) remained unclassifiable. These results are summarized in Table 1.

Table 1. Classification of rumen streptococcal strains isolated from the bottle counts particularly with mannitol $(M N)$ maltose $(M L)$ and xylose $(X L)$ as fermentable carbohydrates

Four tests : growth at pH 9.6; fermentation of mannitol, starch and inulin: in that order.

Typical and atypical rumen amylolytic streptococeus

$\overbrace{\begin{array}{rr}\begin{array}{l}00++ \\ 27(\mathrm{MN})\end{array} & \mathbf{0}+++ \\ 10(\mathrm{ML}) & \text { patterns }\end{array}}$

45 in all

+53 from other sugars

(see p. 143)

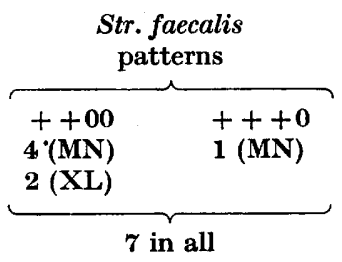

Since the presence in the rumen of bacteria closely resembling Str. faecalis, although in relatively very small numbers, seemed of some interest, a fresh count was carried out with mannitol bottles in March 1953 on the rumen contents of hay-fed sheep no. 879 (the animal used by Heald et al.). Every colony developing at dilutions $1 / 10,000$ and $1 / 70,000$ was transferred to mannitol peptone water, and when fermentation took place, the culture was purified by plating and put through the usual series of fermentation and other tests. In this way five additional strains of Str. faecalis (pattern ++00 ) were isolated, together with five similar strains of pattern $++0+$, differing only in their power of fermenting inulin. All ten strains grew at $45^{\circ}$ and all fermented in addition (with production of acid and no gas) lactose, salicin, raffinose, sorbitol and trehalose. None liquefied gelatin. Five out of ten strains survived heating at $60^{\circ}$ for $30 \mathrm{~min}$. All clotted and decolorized litmus milk. Save for the fermentation of raffinose, a property shared by all the so-called Str. faecalis strains isolated in this study, this behaviour is in harmony with that of Str. faecalis from human sources. In point of fact an authentic strain of Str. faecalis (NCTC 775) also fermented raffinose under our conditions.

The Gram-positive cocci of the hay fed to sheep no. 879. A study of the facultative anaerobic microflora of the fodder was made to find whether the rumen Str. faecalis was in reality merely a 'passenger' derived from the hay, which being kept in quantity before use in an open box might have collected bacteria from the dust in the air. The fairly finely divided hay (10 g. of an average sample) was shaken with sterile Ringer's solution (25 ml.) first by hand for $10 \mathrm{~min}$., and finally on the machine for $45 \mathrm{~min}$. The fluid part was decanted into a sterile centrifuge tube, and the deposit obtained after long centrifuging at 2000 r.p.m., was re-suspended in sterile Ringer's solution (5 ml.). The bottlecounting procedure (Heald et al. 1953) was then carried out on this liquid, 
glucose being used as fermentable carbohydrate. Contrary to the results of Heald et al. (1953) with a different sample of hay, an almost exclusively streptococcal flora developed in this instance. Twenty colonies were picked at random and were purified by repeated plating on glucose yeast-extract peptone agar. After purification, all isolated strains behaved exactly as Str. faecalis, i.e. grew at $\mathrm{pH} 9 \cdot 6$, and in $6.5 \% \mathrm{NaCl}$, fermented mannitol and trehalose, but not starch. They also clotted and decolorized litmus milk. In further resemblance to the rumen Str. faecalis, all strains fermented raffinose. Some strains also fermented inulin (see above).

Just after this experiment the hay fed to the sheep was changed, the fodder box being charged with newly purchased hay. An attempt to study the streptococcal flora of this new hay failed however, the only colonies developing in the bottle counts being Gram-positive rods which overgrew everything else when colonies in the depths of the agar were plated out. It has not therefore been possible to find whether the Str. faecalis in the old hay was really derived from the hay itself, or from the dust of the animal house in which the sheep was kept.

Other Gram-positive cocci from the rumen. A few of the isolates reported as streptococci by Heald $e t$ al. (1953, see Table 2 in that paper) were found upon re-examination to be staphylococci or micrococci. They yielded large catalasepositive non-haemolytic colonies on blood agar and showed bacteria in tetrads and groups, as well as in short chains, in stained preparations. For example, four out of fifty isolates from the mannitol bottles, six out of twelve from the glucose bottles, five out of twelve from the raffinose bottles and two out of twenty-one from the salicin bottles conformed to this description. They were re-examined at the same time as other isolates definitely reported by Heald et al. as 'other Gram-positive cocci'. Twelve representative strains were examined by the methods of Shaw et al. (1951). The cultural characters as found are listed in Table 2, and it will be seen that with one exception, viz. the culture from the sucrose bottle count, they are all vp-positive and conform in most other respects to subgroup 2 of the classification of Shaw et al. (see their table 1, p. 1017). In view of the very weak fermentation reactions of the solitary 'sucrose' strain it may perhaps best find a place in their subgroup 5 . It is remarkable, however, that it should hydrolyse starch. This property may indicate its role in the rumen.

Coliform bacteria. Although some 150 isolates of coliform bacteria were obtained, mostly from the mannitol and xylose bottle counts, a complete study of all these strains was not made since their relative numbers in the rumen, when the sheep is on a hay diet, are quite small, being merely of the order of $10^{4}-10^{5} / \mathrm{g}$. wet rumen contents. Six strains from mannitol, six from xylose, three from rhamnose and three from sorbitol bottles were chosen at random and were all found to be typical intestinal Escherichia coli by IMViC reactions and gas production from lactose at $44^{\circ}$. Capsulation was not found in any of the 150 strains (observation by Miss Elizabeth Mackay using the indian ink technique), and it is highly probable that very few indeed, if any, corresponded to the typical Aerobacter aerogenes. 
Table 2. Cultural characters of rumen micrococci

No. of strains isolated ...

Opt. temperature: $\mathbf{2 2 ^ { \circ }}$

$30-37^{\circ}$

Pigment on potato: none lemon-yellow

$\mathrm{NH}_{3}$-salt utilization golden-yellow

MR positive

VP positive

$\mathrm{H}_{2} \mathrm{~S}$ produced

Nitrate reduced

Methylene blue reduced

Litmus milk: no change acid acid clot

Gelatin liquefied digestion

Serum digested

Coagulase positive

Acid from:* glucose

Urea hydrolysed

xylose
galactose
lactose
sucrose
maltose
raffinose
starch
dextrin
glycerol
mannitol
dulcitol
salicin
trehalose

Sugar used in bottle count for isolation

\begin{tabular}{ccccc}
$\begin{array}{c}\text { Glucose } \\
5\end{array}$ & Raffinose & Xylose & Sucrose & Salicin \\
$\mathbf{3}$ & $\mathbf{1}$ & 1 & 2 \\
& \multicolumn{1}{c}{ Properties of strains } \\
\hline
\end{tabular}

\begin{tabular}{lllll}
\hline $\mathbf{0}$ & $\mathbf{0}$ & $\mathbf{0}$ & $\mathbf{0}$ & $\mathbf{0}$ \\
$\mathbf{5}$ & $\mathbf{3}$ & $\mathbf{1}$ & $\mathbf{1}$ & $\mathbf{2}$ \\
$\mathbf{5}$ & $\mathbf{3}$ & $\mathbf{1}$ & $\mathbf{0}$ & $\mathbf{0}$ \\
$\mathbf{0}$ & $\mathbf{0}$ & $\mathbf{0}$ & $\mathbf{1}$ & $\mathbf{0}$ \\
$\mathbf{0}$ & $\mathbf{0}$ & $\mathbf{0}$ & $\mathbf{0}$ & $\mathbf{2}$ \\
$\mathbf{4}$ & $\mathbf{0}$ & $\mathbf{1}$ & $\mathbf{1}$ & $\mathbf{0}$ \\
$\mathbf{5}$ & $\mathbf{0}$ & $\mathbf{1}$ & $\mathbf{0}$ & $\mathbf{2}$ \\
$\mathbf{5}$ & $\mathbf{3}$ & $\mathbf{1}$ & $\mathbf{0}$ & $\mathbf{2}$ \\
$\mathbf{0}$ & $\mathbf{0}$ & $\mathbf{0}$ & $\mathbf{0}$ & $\mathbf{0}$ \\
$\mathbf{5}$ & $\mathbf{3}$ & $\mathbf{1}$ & $\mathbf{0}$ & $\mathbf{0}$ \\
$\mathbf{5}$ & $\mathbf{3}$ & $\mathbf{1}$ & $\mathbf{1}$ & $\mathbf{2}$ \\
$\mathbf{0}$ & $\mathbf{3}$ & $\mathbf{0}$ & $\mathbf{1}$ & $\mathbf{0}$ \\
$\mathbf{0}$ & $\mathbf{0}$ & $\mathbf{1}$ & $\mathbf{0}$ & $\mathbf{2}$ \\
$\mathbf{5}$ & $\mathbf{0}$ & $\mathbf{0}$ & $\mathbf{0}$ & $\mathbf{0}$ \\
$\mathbf{5}$ & $\mathbf{0}$ & $\mathbf{0}$ & $\mathbf{0}$ & $\mathbf{0}$ \\
$\mathbf{5}$ & $\mathbf{0}$ & $\mathbf{0}$ & $\mathbf{1}$ & $\mathbf{2}$ \\
$\mathbf{0}$ & $\mathbf{0}$ & $\mathbf{0}$ & $\mathbf{0}$ & $\mathbf{0}$ \\
$\mathbf{0}$ & $\mathbf{0}$ & $\mathbf{0}$ & $\mathbf{0}$ & $\mathbf{0}$ \\
$\mathbf{5}$ & $\mathbf{3}$ & $\mathbf{1}$ & $\mathbf{1}$ & $\mathbf{2}$ \\
& & & (weak) & \\
0 & 0 & 0 & 0
\end{tabular}

$0 \quad 0$

$5 \quad 3$

5 3

5 3

53

10

0

5

3

(1 weak)

$\mathbf{5}$

$\mathbf{3}$

0

0

$\mathbf{0}$

$\mathbf{0}$
$\mathbf{0}$
$\mathbf{3}$
$\mathbf{3}$

$\begin{array}{ll}\mathbf{0} & \mathbf{0} \\ \mathbf{0} & \mathbf{2} \\ \mathbf{0} & \mathbf{2} \\ \mathbf{0} & \mathbf{2} \\ \mathbf{1} & \mathbf{2} \\ \text { (weak) } & \end{array}$

$\begin{array}{ll}\mathbf{0} & \mathbf{0} \\ \mathbf{1} & \mathbf{0} \\ \mathbf{0} & \mathbf{2}\end{array}$

0

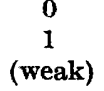

0

0

1

1

$\begin{array}{ll}\mathbf{0} & \mathbf{0} \\ \mathbf{0} & \mathbf{0} \\ \mathbf{0} & \mathbf{2} \\ \mathbf{0} & \mathbf{2}\end{array}$

* No strain fermented arabinose, rhamnose, inositol, inulin, adonitol or aesculin.

'Other Gram-negative rods' mentioned by Heald et al. (1953), which on isolation appeared not to ferment lactose on MacConkey agar, were later found to ferment this sugar slowly in a liquid medium. Five strains were examined in detail (three from raffinose and two from mannitol bottle counts) and all proved to be motile, indole-negative, methyl red-negative, vP-positive, citrate-positive, gelatin-liquefying non-capsulated, small Gram-negative rods, that is conforming in all respects to Aer. cloacae, rather than to Aer. aerogenes.

Gram-negative cocci. Heald et al. (1953) isolated several pure cultures of Gram-negative cocci from the mannitol and xylose bottle counts. Nine 
isolates from the xylose bottles and one from a mannitol bottle were examined in detail and proved to be identical in all respects. This organism, which grows well in ordinary nutrient media, appears to be the well-known rumen sarcina, photomicrographs of which have already been published by Baker et al. (1950, figs. 43-45) and Moir \& Masson (1952, organism no. 26, figs. 10, 16 and 17). Although our isolates were neither iodophile nor capsulated in pure culture on artificial media, nevertheless the large size, sarcina-like arrangement and persistent Gram-negative nature of the cocci render an identification with Baker's rumen organism (which he did not isolate) highly probable. In spite of its Gram-negative character, we propose to place this organism in the genus Sarcina and to name it $\boldsymbol{S}$. bakeri, after the late F. Baker, whose elegant photographic techniques have brought to light many clues for the identification of true rumen bacteria of medium size.

Sarcina bakeri n.sp. Spherical or slightly oval cocci $4 \mu$. in diameter or larger when first isolated; dwindling to 1-2 $\mu$. after many subcultures on artificial media; occurring in pairs (with long axes parallel), tetracocci or closely packed larger groups. Non-motile, no endospores. Capsules not observed in pure culture, although said to be present in the rumen of a sheep receiving starch in the ration (Moir \& Masson, 1952). Gram-negative always, even when young. Colonies on nutrient agar raised, greyish white, translucent with entire edge, 1.3-2 mm. diameter. Grows readily in nutrient broth, forming smooth uniform turbidity with abundant deposit and thin, easily disintegrated surface pellicle. Facultative anaerobe. Grows vigorously at 30 and $39^{\circ}$, but only poorly at $20^{\circ}$. Ferments glucose only, with production of acid but no gas. Grows well in non-carbohydrate media such as peptone water. Does not liquefy gelatin, nor change litmus milk. Catalase-positive. Voges-Proskauer, methyl red, indole and $\mathrm{H}_{2} \mathrm{~S}$ tests all negative. Does not reduce nitrate. Isolated at Bucksburn, Aberdeenshire, from the rumen of a hay-fed sheep in 1952. The products from a glucose fermentation by $S$. bakeri are now under examination.

\section{DISCUSSION}

It has recently been recognized (Hungate, Dougherty, Bryant \& Cello, 1952) that saccharolytic bacteria, particularly streptococci, even if at one time present in relatively small numbers in the rumen, may nevertheless quickly become of much greater importance later on when the soluble carbohydrate content of the fodder is suddenly increased by drastically altering the ration fed to the animal. The sheep we have worked with was kept on the simplest possible ration (hay) containing very little starch or soluble sugar. Hence in all probability the saccharolytic rumen micro-flora found is numerically at the basic minimum, and it would be unwise to infer that the intestinal coliform bacteria, which seemingly constitute a very small part of it, are not 'true' rumen organisms, and that they could never under any circumstances play an important role in the rumen. It is significant that Aer. aerogenes, the common saprophyte found on plants and grains, was not found in the rumen. Furthermore, the short-term fermentation studies of Heald (1952) with xylose and 
rumen liquor, showed that coliform bacteria of the intestinal type are in a very active state in the rumen since they grew very rapidly indeed and soon predominated when the pentose was supplied. Our bottle counts with xylose also yielded numerous coliform bacteria of the intestinal type, partly no doubt because the predominant rumen streptococcus does not ferment this sugar (MacPherson, 1953).

There seems also to be a great diversity of fermentative pattern among the rumen streptococci, some of which are unclassifiable at the moment. It would be of interest to know whether this diversity is found in lambs beginning to ruminate, or whether it is a function of the age of the sheep.

The isolation in pure culture of a large Gram-negative sarcina-like organism, which on morphological grounds alone may almost certainly be regarded as a true rumen organism since it has so frequently been seen in rumen contents, is, we think, good evidence of the essential soundness of our bottle counting and isolation technique. It is at first sight surprising that this and many other isolates failed to ferment, in peptone water, the carbohydrates added to the agar in the bottles from which they were isolated. In the case of $S$. bakeri, this might have been due to the ability of the organism to grow on amino acids alone. In other instances, e.g. streptococci from mannitol bottles, it would seem that other bacterial colonies (coliforms?), developing in the same bottle, provided nutriment for the non-mannitol-fermenting streptococci. Such symbiotic relationships are probably very common in the rumen, and some of them may be brought to light only if, as in our technique, an agar containing the minimum amount of nutriment is used for the isolation of the rumen bacteria.

\section{REFERENCES}

Baker, F., Nasr, H., Morrice, F. \& Bruce, J. (1950). Bacterial breakdown of structural starches and starch products in the digestive tract of ruminant and non-ruminant mammals. J. Path. Bact. 62, 617.

Bergey's Manual of Determinative Bacteriology, 6th ed. (1948). Ed. by BREED, R. S., Murray, E. G. D. \& Hrtchens, A. P. London: Ballière, Tindall and Cox.

Fuller, A. T. (1938). The formamide method for the extraction of polysaccharide from haemolytic streptococci. Brit. J. exp. Path. 19, 130.

Heald, P. J. (1952). The fermentation of pentoses and uronic acids by bacteria from the rumen contents of sheep. Biochem. J. 50, 503.

Heaid, P. J., Krogh, N., Mann, S. O., Appleby, J. C., Masson, F. M. \& Oxford, A. E. (1953). A method for direct viable counts of the facultatively anaerobic microflora in the rumen of a sheep maintained on a hay diet. J. gen. Microbiol. 9, 207.

Hungate, R. E., Dougherty, R. W., Bryant, M. P. \& Cello, R. M. (1952). Microbiological and physiological changes associated with acute indigestion in sheep. Cornell Vet. 42, 423.

Mackie, T. J. \& McCartney, J. E. (1950). Handbook of Practical Bacteriology, 8th ed. Edinburgh: Livingstone.

MacPherson, M. J. (1953). Isolation and identification of amylolytic streptococci from the rumen of the sheep. J. Path. Bact. 66, 95.

Manual of Methods for Pure Culture Study of Bacteria (1948-9). Edited by the Committee of Bacteriological Technic of the Society of American Bacteriologists. Geneva, N.Y.: Biotech Publications. 
Moir, R. J. \& Masson, M. J. (1952). An illustrated scheme for the microscopic identification of the rumen micro-organisms of sheep. J. Path. Bact. 64, 343.

Shatrock, P. M. F. \& Hrrsch, A. (1947). A liquid medium buffered at pH $9 \cdot 6$ for the differentiation of Streptococcus faecalis from Streptococcus lactis. J. Path. Bact. 59, 495.

Shaw, C., StitT, J. M. \& Cowan, S. T. (1951). Staphylococci and their classification. J. gen. Microbiol. 5, 1010.

(Received 5 August 1953) 